\title{
Ecuador, the Digital Divide and Small Tourism Enterprises
}

\author{
Stan Karanasios \\ Victoria University, Australia
}

\begin{abstract}
This article explores the digital divide from the perspective of Ecuadorian small tourism enterprises. Ecuador's ICT environment has been described as underdeveloped, obsolete, and expensive to use. There is also a serious shortage of ICT related human capital. Given these stumbling blocks, this article seeks to identify how small tourism operators have managed to adopt the Internet. Adopting a qualitative approach, field interviews were conducted with tourism enterprises across rural, semi-rural, and metropolitan areas of Ecuador. This article adds to our understanding of the digital divide, especially from the point of view of small tourism enterprises, and serves as an example to other small tourism enterprises in developing countries seeking to adopt the Internet.
\end{abstract}

\section{Keywords}

Digital divide, tourism, small enterprises, Ecuador, Internet

\section{Introduction}

There is a growing body of literature that contributes to our understanding of the challenges faced by small enterprises in developing countries when adopting the Internet. Some of the most commonly cited obstacles are the inadequate and unreliable telecommunications infrastructure (Hawk 2004; Jennex, Amoroso and Adelakun 2004), the cost associated with adopting and using the technology (Cloete, Courtney and Fintz 2002; Rizk 2006), a lack of knowledge and skills, and often businesses are unaware of the full potential of the Internet (Moodley and Morris 2004; Rizk 2006). Referring to Internet adoption in the context of small businesses in developing countries Eduardo da Costa (2001 p.129) commented 'it is difficult, and yes, it is possible'. However, faced with so many organisational and environmental limitations, and often-turbulent political and macroeconomic circumstances, how are small enterprises in developing countries adopting the Internet? Overall, the literature suggests that little Internet adoption is taking place amongst small enterprises (Moodley and Morris 2004; Rizk 2006). For instance, evidence from an investigation by Croes and Tesone (2004) in Nicaragua and Costa Rica showed that less than thirteen percent of Costa Rican, and less than two percent of Nicaraguan small and medium sized enterprises (SMTEs) advertised on the Internet. Email was the most widely used online activity, although SMTEs indicated a preference for interaction through low-tech means such as cell phones. While the least common uses

Copyright (C) 2007 Victoria University. This document has been published as part of the Journal of Business Systems, Governance and Ethics in both online and print formats. Educational and non-profit institutions are granted a nonexclusive licence to utilise this document in whole or in part for personal or classroom use without fee, provided that correct attribution and citation are made and this copyright statement is reproduced. Any other usage is prohibited without the express permission of the were advertising and selling or buying goods on the Internet. Similarly, a large study carried out by the Asia Foundation on SMEs in Philippines, Thailand, Sri Lanka, and Indonesia revealed that very basic uses of the Internet were taking place. This included email communication between suppliers and customers, research 
and information gathering, and to a lesser extent the development of basic websites (Asia Foundation. 2005). In Morocco, Mann (2002) found that most small tourism operators did not have informative websites and could not even receive reservations by email because of the high telecommunications cost involved. Mann also established that business lacked familiarity with the Internet and the ability to design a website. In Peru, a study by Gartner (2004) on small tourism operators found that they were all dependant on Lima based intermediaries who dealt directly with international agents that controlled prices. Even though the Internet emerged as a vehicle to bypass intermediaries, little adoption was taking place. Small local operators explained that such a move would be viewed as hostile by the Lima based agents who had threatened before to stop providing services to any operator that had the audacity to act in such a manner.

While the challenges faced by small enterprises and their use of the Internet is well explored, there is a paucity of research focusing on how they actually contend with these underlying constraints. In other words, how are small businesses overcoming the inherent obstacles in their environments and adopting the Internet? To answer this question, this article shares the experiences of Ecuadorian small tourism operators and provides a new perspective of the realities faced by small businesses in the developing world.

This article is organised as follows. The following section discusses the relationship between the Internet and tourism. A description of how the study was conducted is then presented. The subsequent section is dedicated to a discussion of the Information and Communication Technology (ICT) and small business environment in Ecuador. The experiences of the Ecuadorian tourism enterprises are then discussed. Finally, the article concludes with some discussion and lessons for small tourism enterprises.

\section{The Internet and Tourism}

For sometime tourism has been recognised as an information-based and information-intensive industry that is well suited to the Internet (Poon 1993; Inkpen 1994; Sheldon 1997). Of little surprise, the numbers of people that use the Internet to plan trips are increasing. Over 84 million Internet users around the world visited travel sites in June 2001 (WTO 2002). In fact, the Internet 'has become one of the most successful channels used by consumers to research travel options, compare prices and make reservations' (Collins, Buhalis \& Peters 2003 p.484). From the business perspective it has emerged has the most relevant technology for marketing and communication, receiving bookings, information gathering, and internal operations (Gammack, Asia Pacific Economic Cooperation (Organization). Tourism Working Group., Griffith University School of Management. and APEC International Centre for Sustainable Tourism. 2004). Now, most large hotels have extensively adopted the Internet, developing websites, using the Internet to improve communications and creating new distribution channels (Collins, Buhalis and Peters 2003).

Although traditionally, smaller tourism operators have lagged behind their larger counterparts in terms of technology adoption, the Internet has been described as empowering even tiny tourism enterprises (Buhalis 1999). In the context of developing countries, Purcell et al., (2004) identified a number of benefits that have been linked with small tourism enterprise Internet use in developing countries. The benefits included, reduced advertising and communication costs, more efficient access to information, and exposure to a wider audience. This suggests that small tourism enterprises that do not adopt the Internet are placing themselves at a considerable disadvantage. Furthermore, it suggests that identifying strategies that can assist small tourism operators to mitigate Internet adoption barriers is imperative to facilitate its widespread adoption. In this article a number of specific examples are drawn from the field research to offer insight into the challenges faced and the solutions applied by small tourism enterprises in Ecuador. By doing so, transferable lessons for other small tourism businesses considering Internet adoption are identified. 


\section{The Study}

The overarching aim of the study was to investigate small tourism enterprise 'e-readiness' and Internet use in developing countries. As a result of the study an e-readiness framework was developed to assist small tourism enterprises in developing countries to make decisions about e-commerce. Field research was conducted in Malaysia and Ecuador. However, this article concentrates solely on the Ecuadorian component of the study and specifically the ways that small tourism enterprises contended with Internet adoption obstacles.

This study is classified as a multiple-case study. Field interviews were selected over other data collection techniques such as questionnaires, because interviews are valuable for developing an understanding of a phenomenon at the 'grass-roots' level (Neuman 1997). Enterprises had to fulfil three conditions to be eligible for the study. The first was that they must have less than twenty employees. The number of employees was considered as the principal criteria because of the difficulty obtaining information such as sales turnover or capital. The second condition was that they must be either an accommodation provider and/or a tour operator. The reason for this was because these two categories of tourism enterprises operate by attracting customers based on information provided. Focusing on a particular type of small business overcomes industry differences and strengthens validity (Cragg and King (1993) cited in Faggiani (2005)). It also means that the lessons learnt may be applicable to other small tourism enterprises. The final condition was that enterprises should use the Internet (as per Purcell et al., 2004). To avoid any language problems participants were informed that all interviews would be carried out in English. This posed only a minor issue, as most participants were fluent in English. To gather a holistic picture of the situation in Ecuador, rural, semi-rural, and metropolitan enterprises were targeted to participate.

Because personal introductions are often an integral part of the culture in developing countries, it was expected that the level of response to the initial email invitation would be low. Therefore, a large number of small tourism enterprises were emailed to participate. To achieve this multiple sources were used to collect the details of small tourism enterprises. This involved obtaining email addresses from commercial tourism websites (as per Davidson et al., (2006)), and traditional media such as travel guidebooks. During the course of the field research twelve in-depth field interviews were performed. The field research began on April the $19^{\text {th }} 2006$, and concluded on the $25^{\text {th }}$ of May 2006. Although this study is classified as a multiple-case study, there are many similarities with ethnography as the field research involved interacting with small business owners in their social contexts. A reason for using ethnography to study actual real world situations (such as a small business) is because it enables a researcher to observe and study businesses as the complex social, cultural, and political systems that they are (Harvey and Myers 2002). In this case, the researcher spent days with participants in their lodge and surrounding areas, and was able to gain in-depth insight into their environments. The investigation also involved examining the online presences and activities of participants. Hine (2000) labels this as 'virtual ethnography'.

Table 1 lists the location and the types of services offered by each participant. Figure 1 geographically illustrates the location of each participant. There is some difficulty in classifying enterprises as exclusively rural, semi-rural, or metropolitan. For example, two enterprises ran lodges in a remote area, but performed most of the business operations from a home office in Quito. In one case, the home office was simply a computer connected to the Internet. Similarly one enterprise ran most of the tour/lodge operations (the Internet side) from a home office in a semi-rural area (where the tour operations were based) even though the lodge was actually located in a rural area. Customers rarely visited the home offices of these businesses, and in one case the owner spent a considerable amount of time at the actual business (the lodge). In another instance, a participant ran a tour business out of a shop front in Quito, even though its main source of Internet access was from home in a semi-rural area. Classifying businesses like these is a particular conundrum in a study such as this one where the area of interest is the Internet. However, such issues are typical when researching small businesses because they are managed in a personalised way (Kuwayama 2001) and not amenable to clear categorisation. 
Table 1: Profile of the small tourism operators

Figure 1: Map of Ecuador

\begin{tabular}{|l|l|}
\hline Location & Services \\
\hline Otavalo & Lodge \\
\hline Puerto Ayora & Tour operator \\
\hline Quito & Tour operator \\
\hline Quito & Tour operator \\
\hline $\begin{array}{l}\text { Quito - } \\
\text { Baeza* }\end{array}$ & Tour operator \\
\hline Cotopaxi & Cabañas \\
\hline Quito & Tour operator \\
\hline $\begin{array}{l}\text { Quijos } \\
\text { Valley }\end{array}$ & Hacienda \\
\hline Sangolqui & Hacienda \\
\hline Quito & Small hotel \\
\hline Chugchilán & Eco-lodge \\
\hline $\begin{array}{l}\text { Tumbabiro - } \\
\text { Conocoto }\end{array}$ & $\begin{array}{l}\text { Lodge \& tour } \\
\text { operator }\end{array}$ \\
\hline
\end{tabular}

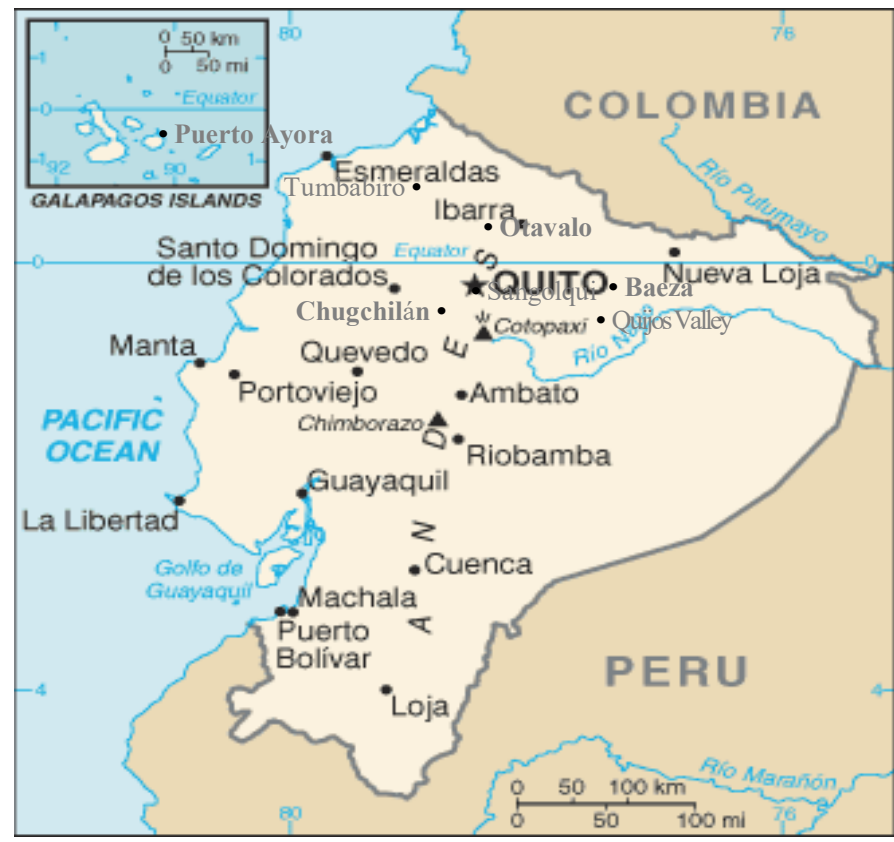

Adapted from: CIA (2007)

Note: 'Hacienda' is a Spanish word referring to a large countryside ranch, estate, or farm.

'Cabañas' is a Spanish word referring to a small hut type of dwelling.

* This tour operator used the Internet from home in a semi-rural area.

Before entering into the field, a background analysis was performed on the state of affairs in Ecuador. This formed an important part of the analysis process, and helped to explain emerging themes (Dawson 2002). Despite the contemporary nature of the subject extensive documentation was not available. Along these lines, Angelelli et al., (2003) in a report for the Inter-American Development Bank posited that limited information is generally available in terms of information on small enterprises in Latin America. The background investigation involved a reconstruction of the ICT environment. It also involved becoming familiar with the geography, history, politics, and culture of the people to be studied (Peil 1983). This approach has been used in other ICT studies in the context of developing countries (Montealegre 1998; Madon 2005), and entails a thorough review of journal articles, government and institution reports, and other relevant literature.

\section{Ecuador: ICTs and small enterprises}

The Republic of Ecuador is located in the Andean region of South America. It is a resource rich country with a population made up of a variety of cultures and ethnic groups. Ecuador is the world's largest producer of bananas and significant producer of oil. In fact, oil contributes around one third of government revenue, comprises 20 percent of the economy, and 45 percent of exports (Economist 2005; CountryWatch 2006). Nevertheless, despite its resource affluence, a wide income gap places most of the population in the condition of extreme poverty (Talamanca, Furlani and Alves 2006). Before discussing Ecuador's ICT environment, it is useful to begin by presenting a brief overview of the country in recent years. Nazmi (2001 p. 727) summed up the 1990's by suggesting that while other Latin American countries were implementing meaningful economic reforms 'Ecuador found itself in political chaos, social rift, regional infightings, and economic uncertainty'. It is no surprise then that the new millennium began poorly for Ecuador. Political instability and coups d'État resulted in four presidents 
in five years - at one point in 2005 there were two contenders claiming to be president (Economist 2005).

Furthermore, high inflation and resulting 'dollarization', unemployment and low growth affected macroeconomic stability (Nazmi 2001; Economist 2006; Talamanca, Furlani et al. 2006). However, very recently there has been some economic and political stabilisation (Talamanca, Furlani et al. 2006).

There exists little reported information concerning ICTs in Ecuador, as is the case with other Latin American countries (Guasch and Ugas 2007). ICT development has not been a priority of policy makers. This is reflected in the country's e-readiness ranking, which decreased from 2002 to 2007 (Kirkman, Cornelius, Sachs and Schwab 2002; EIU. 2004; Dutta and Lopez-Claros 2005; EIU. 2007). As a result, the country suffers from an underdeveloped, obsolete, and expensive to use ICT infrastructure (Talamanca, Furlani et al. 2006). Furthermore, there is a limited supply of ICT related human capital, such as engineers, programmers, and website designers (Coppock, Maclay and Calero 2002; Talamanca, Furlani et al. 2006).

Teledensity remains low in Ecuador. Over 60 percent of the telephones lines are located in the capital Quito and the two other largest cities Guayaquil and Cuenca, which account for less than one third of the population. In terms of Internet users, as at 2005 there were seven Internet users per 100 people (ITU 2005). (Table 2 displays some basic demographic and ICT indicators for Ecuador).

Table 2: Ecuador Internet \& ICT Indicators

\begin{tabular}{|l|l|l|l|l|l|}
\hline Population & $\begin{array}{l}\text { Rural \% of } \\
\text { population }\end{array}$ & $\begin{array}{l}\text { Hosts per } \\
10 \text { '000 } \\
\text { inhabitants }\end{array}$ & $\begin{array}{l}\text { Internet users } \\
\text { per 100 } \\
\text { inhabitants }\end{array}$ & $\begin{array}{l}\text { PCs per } \\
100 \\
\text { inhabitants }\end{array}$ & $\begin{array}{l}\text { Average monthly } \\
\text { cost per 20hrs } \\
\text { Internet access }\end{array}$ \\
\hline 13.2 million & $35.5 \%$ & 6.67 & 7.32 & 5.49 & SUS 20.61 \\
\hline
\end{tabular}

Compiled from: (Kirkman, Cornelius et al. 2002; ITU 2005; WorldBank 2006)

\section{Small Enterprises in Ecuador}

Ecuador is a market economy characterised by small-scale service and farming enterprises and high levels of self employment (Acs 2006; CountryWatch 2006). It is not surprising then that small businesses are the most important source of job creation (Talamanca, Furlani et al. 2006). In fact, 99 percent of all private enterprises have no more than 50 employees (World Bank. 2000). However, the country lacks significant policies geared towards small businesses, and resources to address capacity building and ICT diffusion (Talamanca, Furlani et al. 2006).

In addition to the inherent characteristics of small enterprises, such as being resource poor, having basic technology needs, being informally run, and relying on family labour (Mead and Liedholm 1998; Turner 2003; Bannock 2005; Oyelaran-Oyeyinka and Lal 2006), there is a prevailing organisational culture in Ecuador that does not see ICT implementation as a driver of change (Talamanca, Furlani et al. 2006). Busch (1989) also identified some characteristics of the small business environment in Ecuador:

- There is a lack of educated and trained personnel.

- Many small business owners believe that non-family members cannot be trusted and employees cannot be relied upon to follow directions.

- Although the city of Quito has an association of small businesses, the concept of trade associations does not appear to be well understood or fully accepted.

- Business owners and managers tend to be rather secretive and unwilling to share information.

The foregoing discussion suggests that factors such as an inadequate and expensive to use telecommunications infrastructure, lack of supportive government policies geared towards small business for ICT diffusion, and a lack of skilled human resources act as Internet adoption barriers in Ecuador. The subsequent section will discuss how these factors affected the small tourism enterprises in this study. It will also identify the ways that participants contended with these challenges. 


\section{Discussion of the Field Research}

\section{Small Tourism Enterprise Uses of the Internet}

Before discussing the experience of the participants in this study, it is useful to identify how they were making use of the Internet. All participants had a website. The websites were relatively basic, although there was some use of moving images and content in multiple languages. Despite the simplicity of the websites, they appeared easy to use and navigate, although this was the impression of the author and not verified through any performance analysis. There was widespread use of tourism and travel portals for promotion. Email was the main use of the Internet. In fact, eight of the participants received over 50 percent of bookings through email. Only two enterprises actually offered online payments. However, both participants indicated that the volume was quite low. The most complicated internal infrastructure was a handful of networked computers. The use of the Internet by participants is consistent with development authors that suggest that small enterprises in developing countries concentrate on basic online activities (Tanburn and Singh 2001; Duncombe, Heeks, Kintu and Nakangu 2004). The next section will discuss how participants contended with the Internet adoption obstacles they faced. Four key areas are discussed, the cost of adoption, the ICT infrastructure, government support, and a lack of ICT skills. These are four of the major Internet adoption obstacles in Ecuador as revealed by the literature review and content analysis of the qualitative data gathered in the field.

\section{Cost of Adoption}

The experience of the data collection suggested that the financial burden associated with Internet adoption was an issue for the participants, although not necessarily an inhibiting factor (however, this study only targeted online tourism operators). The cost of adoption did influence the types of activities that were performed online, and may help to explain why participants have not progressed beyond the entry-level stage of Internet use.

In Ecuador the cost of ICTs are quite high. In fact, three participants even went so far to suggest that the cost of ICTs in Ecuador was higher than in much more affluent countries such as the USA. As an example, participants in this study paid around \$US 75 a month for broadband (Ecuador GNI per capita is \$US 2210). Whereas a study by the authors in 2005/06 in Malaysia found the average cost was \$US 21 a month (Malaysian GNI per capita is \$US 4520). A hotel paid \$US 250 per month for a cable Internet access, which was used to provide wireless access to guests. This could be a strategy that other small tourism operators adopt to pass on the cost of Internet adoption.

There was some uncertainty amongst participants concerning the reason for the high cost of ICTs. A tour operator explained that even though the telecommunications industry is privatised the government still plays a role and elicits money from this industry. One participant commented 'cost is not an issue, but everything is expensive!' referring to the high inflation experienced by the country. There was the indication that prices were decreasing - one participant gave the example of how previously an ADSL connection attracted 'an outrageous price of something like 200 [\$US] dollars a month'.

Participants used a number of different means to attenuate the financial burden associated with Internet adoption and use. These are instructive examples for other small tourism enterprises:

- Using friends and family for IT support and advice (rather than pay for professional assistance). It also involved using these informal sources for website development, or developing the website internally, as opposed to paying for the development of one.

- Using simple, low cost online activities such as email and basic web publishing that are inexpensive and require very little maintenance. Again, this may help to explain why participants have not progressed beyond simple entry-level activities.

- Hosting a website in the USA, as opposed to hosting it in Ecuador. This has been found to be the case in other studies (Wresch 2003; Jennex, Amoroso et al. 2004). One enterprise hosted its 
website in the USA at the cost of \$US 9, whereas another enterprise paid as high as \$120 to host its website locally. Along these lines, UNCTAD's (2004) guide for SMEs suggests that businesses in developing countries host their website in the country of it customer base. An international host can also raise the credibility of a business, and reduces fears that customers may have about purchasing from a business in a developing country (Lake 2000).

- Hosting a website with a free hosting service. One enterprise first hosted its website with a free hosting service. Then, once there appeared to be some benefit from having a website, the enterprise moved onto paid hosting. In support of this strategy, Costa (2001) suggests that a small business that has an idea to go online, should do it immediately, and correct it later.

- Using the brand of third-party tourism websites (such as online intermediaries and travel portals). These websites offer resources (such as marketing power and booking engines) that small tourism enterprises would not otherwise have access to. Along these lines, Payne (2002) suggests that small businesses consider 'piggybacking' on someone else's brand. This is important for small tourism enterprises in developing countries, because trust is an important issue, particularly for international customers (UNCTAD 2004).

- Collaborating with other tourism enterprises to develop a greater web presence as opposed to only having an individual website. For instance, one enterprise collaborated with other similar tourism operators. Together they developed a superior website promoting eco-lodges in Ecuador. By pooling their resources they were able to compete more aggressively. In particular they were able to promote themselves on a US based tourism portal that charged approximately $\$ 1500$ per year for promotion. Individually the tourism operators could not afford this level of promotion through their individual websites. In support of this approach, Payne (2002) suggests that small businesses come together to share an electronic commerce innovation.

\section{Government Support}

Echoing the earlier discussion of the ICT environment in Ecuador participants indicated that the government was doing very little to support Internet diffusion amongst small tourism enterprises. In fact, amongst participants there was a negative view of the government. A tour operator remarked ' $I$ ask for nothing and receive nothing' referring to a lack of government support. While another put forth that 'they [the government] do little to help the people or business or tourism', and lamented that the 'government infrastructure is poor, medical, welfare, everything!'

A reply from a small tourism operator to the initial email invitation to participate in the study provides useful insight into the situation in Ecuador:

'Now please be aware that our company might be ready for having full access to internet in any way but the legislation of our country in order to prevent fraud has many stupid rules to say the less. The cost of the service here is 3 or 4 times more expensive than in your country like if Ecuadorians have all the money in the world and worst, here we do not know yet DSL connections. Most of the population still use dial up modems and extremely slow connection. It will be an interesting research what you are doing. It will be like a voyage in time'.

Following a similar train of thought one participant suggested that the government acts as a barrier, 'government is not up-to-date, they have old systems and lines, very bureaucracy [bureaucratic] which makes it difficult to go on Internet on-line' and continued to say 'government is not helping at all. All you have to do private' (meaning that everything has to be done by the business without any support from the government). Unlike the strategies that were employed to attenuate the financial burden of Internet adoption, there was very little that could be done to overcome a lack of government support. As a consequence participants were forced to 'go at it alone'. On the positive side, some participants believed that things were improving. 
Another area where the government was not perceived to be providing assistance was in terms of its online tourism marketing strategy. Other studies have highlighted the importance of government online tourism marketing or e-tourism websites (Purcell, Toland and Huff 2004; Karanasios and Burgess 2006). Consumers generally regard these websites as a source of unbiased and high quality information and they provide resource poor tourism operators with the opportunity to promote themselves online to a large audience. However, in Ecuador, tourism operators explained that there was no successful online marketing strategy by the government (the official website http://www.vivecuador.com/ provided little opportunity for small tourism enterprises to be promoted worldwide). One participant commented that 'their [Ecuadorian government] marketing campaign is extremely poor' and 'government is doing a poor job of marketing tourism'. Along these lines, Talamanca et al., (2006) reported that most government portals in Ecuador are not updated. To combat this, participants made use of other tourism portals for promotion.

\section{ICT Infrastructure}

As observed earlier, Ecuador's ICTs infrastructure is described as underdeveloped, obsolete, and expensive to use (the previous section looked at how participants contended with the cost of using the Internet). Participants shared a number of experiences concerning problems with the infrastructure and described some instructive strategies they used to overcome them.

A tour operator located on a small island in the Galapagos remarked that connectivity was a real issue. This participant was unsure of the type of Internet connection, but labelled it 'the slowest broadband ever'. The business also suffered from regular power outages. To overcome this, the participant resorted to using the Internet at a nearby public Internet access point. Another participant reported that gaining access to dial-up was not problematic, however, 'Banda Ancha' [Broadband] is extremely difficult'! In the months leading up to the interview the business experienced many problems. E-mails were not received and the business experienced poor service and incapable technicians on the part of the ISP 'since 5 days I try to change Internet provider and I am exhausted because the old provider is bothering and is not passing information new provider need. It really is a headache and hopefully new provider can make us on-line within ten days'. The impact of this was that the owners wasted time and resources fixing problems rather than operating the business. This participant also provided some insight into using ICTs in a semi-rural area 'one month ago, they just cut the electricity without warning and computer got broken. Probably people from the electricity are not informed or ignorant that we use computers in Conocoto'. The suggestion from this enterprise was that these types of problems were simply a limitation of operating in a semi-rural area, and one that a business needs to become accustomed to.

In one case, a Quito based bicycle tour operator (that used the Internet from home in a semi-rural area) lamented 'I can ride faster than my connection'. The problem was that the connection was slow and disconnected often. To work around this the owner needed to download emails and then write the response offline. The owner would then return online and send the reply. When the Internet was needed whilst at work (in Quito), the owner made use of cabinas públicas (Internet cafés). However, the owner only used them sparingly because of the cost involved (usually around one to two \$US per hour).

An example set in the Andes of Ecuador, provides an excellent working case of how small tourism enterprises can work around problems with the infrastructure. In this example, the owners of a lodge explained that when they first settled in a remote part of the Andes to setup a lodge there was no telephone line. To rectify this, when the owners used to drive to the nearest large town (roughly four hours drive away) they would stop by the local telephone company, and request in person for a telephone line to be setup in the village. A first line was installed a few years later, and more lines were added in 1999. At that point, the owners began to use the Internet via a dial-up connection, which was extremely expensive (over one hundred US\$ per month including telephone calls), and unreliable. The owners explained that due to a lack of maintenance the quality and reliability of the local telecommunications infrastructure deteriorated rapidly over the last few years it was old technology 
and now it is ancient'. In fact, at the time of the interview, they could only connect via a telephone call about 60 percent of the time, and even then the line was extremely crackly. As a result, it was extremely difficult to hold a conversation. The owners then told the story of how they acquired the idea of using a satellite-dish to access the Internet from a tourist who visited the lodge with one in his van. This gave the lodge owners the idea of using a satellite-dish to access the Internet. After performing a basic costbenefit analysis the owners decided that in the long-term using a satellite-dish would provide a more efficacious means of accessing the Internet. They then embarked on purchasing a second-hand satellitedish from the USA, and had it transported to the nearest town. It is worth pointing out that even without any prior experience in this area, the owners managed to work it out using trial and error. This innovative solution resulted in stable Internet access and decreased telecommunications expenses, and generally as a result of the Internet and their online presence they were able to attract more customers. In fact, because of the deterioration of the existing infrastructure, the Internet became the only reliable means to receive a reservation, and communicate with customers.

Two participants made use of public Internet access points on an occasional basis. Although this represents a small number of the overall participants, it is inline with the attention that public Internet access points have received in the context of developing countries (Romero 2000; Colle and Roman 2005; Harris 2005). This is encouraging for other small tourism enterprises because it suggests that an internal Internet connection is not always necessary. In Ecuador, there has been a focus on the use of public internet access points (Galperin 2005), motivated by factors such as the high price of telecommunications and low PC penetration (Coppock, Maclay et al. 2002).

The preceding discussion suggests that the inadequate and poor infrastructure continues to be an issue in Ecuador. This goes against the argument put forth by some that in a relatively short time infrastructure will cease to be a very significant impediment to ICT development in some countries (Efendioglu and Yip 2004). Having said that, there was the indication that the situation was improving. In this study it appears that participants learnt to work within the confines of their environments. Participants also demonstrated the ability to mitigate certain challenges (using solutions such as working offline, using public Internet access points, and even the installation of a satellite-dish). In support of this, Molla and Licker (2005) assert that while some enterprises may accept organisational and external limitations others will take steps to counteract them, or are able to work in the confines of such constraints.

Some lessons for small tourism enterprises are:

- Learning to work within the confines of their environments. This means becoming accustomed to telecommunications and power outages, slow Internet connections, and other infrastructural limitations. The indication was that despite these shortcomings there are benefits to be absorbed.

- Working offline.

- Using innovative solutions such as purchasing a satellite-dish.

- Making use of public Internet access points.

\section{Skilled Human Resources}

The literature suggests that there is a lack of ICT related human capital in Ecuador. In the context of this study most participants themselves (the owner/managers) were quite Internet savvy. This was a result of self-capacity or previous education. For instance, one participant simply purchased a computer and learnt how to use it. However, there was a problem with the level of ICT skills of the existing employees. Another layer of complexity was added because participants suggested that the problem extended to working knowledge of English to manage the communication component of the job (Spanish is the official language in Ecuador). This is particularly problematic in Ecuador where there are a small number of English speakers (Gordon 2005). The issue was not isolated to rural enterprises where traditionally this problem is more acute. A Quito-based participant even went so far as to check emails that were sent out by employees to make sure that they were correct. This echoes an earlier description of the business environment in Ecuador by Busch (1989). There was also the suggestion that it was too 
expensive to hire an employee that has Internet skills and can communicate well in English. This is another example of how the cost of adopting the Internet can impact the business. Typically where this was not an issue it was because the owner/manager took care of the Internet side of business operations.

This problem referred not only to the existing employees but also to the local human resource base. To combat this issue one participant provided training. However, the owner maintained a cautious approach to training, because of concerns that the employee may leave for a job elsewhere. On the other hand, another participant commented 'we always stimulate employees to improve their skills and we help them also with this in time and economically'.

In the case of a remote enterprise it was difficult to employ locals who could take care of the Internet side of the business. One of the owners explained that they employ 'four reliable young teenage girls that can cook and look after the rooms', however, 'if I train them up on the Internet side of things there is no point because as soon as they hit 19-20 they get married and have children'. For this reason, they hired foreigners (usually travellers who want to stay in one location for a extended period of time) to help manage the lodge.

Participants often turned to informal networks such as family and friends for advice, IT support, website design, and so forth. The indication was that outside of rural areas these types of services existed in abundance, although at a high price. One participant used a teacher at his son's school to develop the first business website. The second website was developed by a paid consultant. Therefore the use of informal networks was not only a method of overcoming a lack of knowledge and skills, but also avoiding expensive professional assistance. It may also be a way of satisfying cultural obligations (Gartner 2004). In fact, other than for website development no outside professional assistance was employed. The echoes the characteristics of small businesses in developed (Burgess, Johanson, Schauder, Karanasios, Stillman and Sellitto 2006) and developing countries (Karanasios and Burgess 2006).

\section{Discussion}

Along with the opportunities that Internet adoption offers small tourism enterprises, it presents significant challenges. The foregoing discussion captured the experience of a small number of tourism operators in Ecuador, and provided insight into the reality of Internet adoption in the context of developing countries. In particular, it examined how tourism operators mitigate the underlying barriers to Internet adoption in Ecuador. Participants used a number of different strategies to attenuate the cost involved with Internet adoption. They also were able to work around or find solutions for the inadequate and unreliable telecommunications infrastructure. In support of this, authors contend that enterprises in developing nations are able to find ways of keeping costs down and circumventing infrastructure shortcomings (Wresch 2003; Karanasios and Burgess 2006). To a lesser extent participants were able to contend with a lack of government support by doing everything themselves, and built self-capacity or made use of informal networks because of a lack internal skills. However, it appears as though these factors will continue to restrain and be obstacles to further development of the Internet amongst small tourism enterprises.

A number of transferable strategies emerged from the qualitative data that can be applied to other small tourism enterprises. Table 2 summarises the strategies employed by participants in this study. Armed with such knowledge small tourism enterprises are in a better position to contend with the obstacles they face. 
Table 2: Strategies used by participants to overcome Internet adoption obstacles

\begin{tabular}{|c|c|}
\hline $\begin{array}{l}\text { ig the } \\
\text { urden of } \\
\text { loption }\end{array}$ & $\begin{array}{l}\text { - Using friends or family for IT support, website design, and advice } \\
\text { - Developing a website internally, as opposed to paying for the } \\
\text { development of one } \\
\text { - Using simple, low cost online activities such as email and basic web } \\
\text { publishing that are inexpensive and require very little maintenance } \\
\text { - Hosting a website in the USA (where the cost is less than in Ecuador) } \\
\text { - Hosting a website with a free hosting service } \\
\text { - Using the brand and resources of third-party tourism websites } \\
\text { - Sharing resources with other tourism enterprises }\end{array}$ \\
\hline $\begin{array}{l}\text { Over } \\
\text { of go } \\
\text { supp }\end{array}$ & no effective \\
\hline $\begin{array}{l}\text { Overcoming the } \\
\text { inadequate and } \\
\text { unreliable } \\
\text { telecommunications } \\
\text { infrastructure }\end{array}$ & $\begin{array}{l}\text { - Learning to work within the confines of their environments. This } \\
\text { means becoming accustomed to telecommunications and power } \\
\text { outages, slow Internet connections and other infrastructural } \\
\text { limitations } \\
\text { - Working offline } \\
\text { - Using innovative solutions such as purchasing a satellite-dish } \\
\text { - Making use of public Internet access points, such as telecentres and } \\
\text { Internet cafés }\end{array}$ \\
\hline $\begin{array}{l}\text { Overcom } \\
\text { of skills }\end{array}$ & 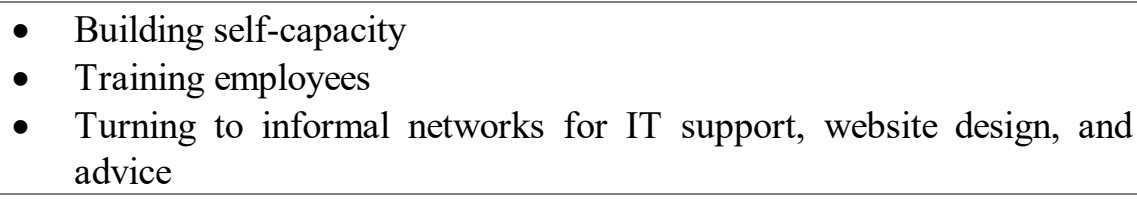 \\
\hline
\end{tabular}

The experiences of the tourism operators in this article demonstrate that different paths have been traversed in the journey to Internet adoption, and a range of conditions encountered. This means that there is no one-size fits all solution for enterprises in developing countries, and that a flexible approach to adoption is required that takes into consideration the business environment and organisational resources. Along these lines, Austin (1990) suggests that the key to effective management in developing countries is the capacity to analyse and understand the forces enveloping the business and translate them into strategic decisions.

This article also highlighted many areas that need to be address in order to facilitate the expansion of the Internet amongst small tourism enterprises in Ecuador. Reducing the price of ICTs and designing specific support programmes for small tourism enterprises such as soft-loans for ICT adoption and capacity building purposes would go someway to assisting small tourism enterprises with Internet adoption. Steps should also be made to strengthen the telecommunication infrastructure to allow for more efficacious Internet use, and strategies employed to address the shortage of ICT related human capital. Furthermore, resources should be allocated to develop an official online tourism portal that provides small tourism operators a platform to promote to a worldwide market. Addressing these issues may also assist small tourism enterprises to progress beyond the entry-level stage of Internet adoption.

Whilst this article focused on a small selection of enterprises, the intention was to gain an understanding of how small tourism enterprises overcame obstacles using a small number of cases. The results from this study are suggestive of the problems faced (to a large extent), and the solutions applied (to a lesser extent) by small tourism enterprises in Ecuador, and many other developing countries. One limitation in this discussion is the point of view of offline tourism operators, or ones that may have tried, but failed, to surmount obstacles. A complementary approach would be to focus on both adopters as well as nonadopters. Nevertheless, this investigation does add to the growing body of literature in the domain of small tourism enterprises and the Internet in developing nations. It is also provides practical lessons for 
small tourism enterprises, development consultants, and researchers as it is one of few articles that examine how small tourism enterprises actually contend with Internet adoption obstacles.

\section{References}

Acs, Z. 2006, 'How is entrepreneurship good for economic growth?' innovations, vol. Winter 2006, pp. 97-107.

Angelelli, P., Guaipatín, C., Almeyda, G. \& Llisterri, J.J. 2003, IDB Group support to the small and medium enterprise sector (1990-2002) achievements, lessons, and challenges, The Inter-American Development Bank Sustainable Development Department Micro, Small, and Medium Enterprise Division, Washington.

Asia Foundation. 2005, Regional survey of SME's use of ecommerce in Indonesia, the Philippines, Sri Lanka and Thailand, viewed December 12 2005, <www.asiafoundation.org>.

Austin, J.E. 1990, Managing in developing countries : strategic analysis and operating techniques, New York : Free Press ; London : Collier Macmillan.

Bannock, G. 2005, The economics and management of small business : an international perspective, Routledge, New York.

Buhalis, D. 1999, 'Information technology as a strategic tool for sustainable tourism development', The Courier, vol. no. 175, no. May-June, pp. 55-7.

Burgess, S., Johanson, G., Schauder, D., Karanasios, S., Stillman, L. \& Sellitto, C. 2006, 'Building capacity in small businesses for the use of the Internet: A study of 'outer' suburbs in Australia', paper presented to SME Entrepreneurship Global Conference 2006, Selangor, Malaysia.

Busch, E.T. 1989, 'Small business hurdles in Ecuador', Journal of Small Business Management, vol. 27, no. 1, pp. $70-4$.

Central Intelligence Agency. 2007, The World Fact Book, Central Intelligence Agency, viewed June 222007 , $<$ https://www.cia.gov/library/publications/the-world-factbook/geos/ec html $>$.

Cloete, E., Courtney, S. \& Fintz, J. 2002, 'Small businesses' acceptance and adoption of e-commerce in the Western-Cape Province of South-Africa', The Electronic Journal on Information Systems in Developing Countries, vol. 10, no. 4, pp. 1-13.

Colle, R.D. \& Roman, R. 2005, 'Towards demand-driven community telecentres', in R.M. Davison (ed.), Information systems in developing countries : theory and practice, City University of Hong Kong Press, Hong Kong, pp. 114-29.

Collins, Buhalis, D. \& Peters, M. 2003, 'Enhancing SMTEs' business performance through the Internet and elearning platforms', Education Training, vol. 45, no. 8, pp. 483-94.

Coppock, K., Maclay, C. \& Calero, L.A. 2002, 'Ecuador Country Profile', in G.S. Kirkman, P.K. Cornelius, J.D. Sachs \& K. Schwab (eds), The Global Information Technology Report 2001-2002 Readiness for the Networked World, Oxford, New York, pp. 194-5.

Costa, E.d. 2001, Global E-commerce Strategies for Small Businesses, MIT Press, Cambridge, Mass. ; London.

CountryWatch 2006, Ecuador 2006 Country Review, CountryWatch, viewed December 92006 , $<$ www.countrywatch.com>.

Croes, R.R. \& Tesone, D.V. 2004, 'Small firms embracing technology and tourism development: evidence from two nations in Central America', International Journal of Hospitality Management, vol. 23, pp. 557-64.

Davidson, A., Burgess, S. \& Sellitto, C. 2006, 'An investigation of SMTE Web Site usage in Australia: Implications for E-commerce adoption and planning processes’, in N. Al-Qirim (ed.), Global Electronic Business Research: Opportunities and Directions, Idea Group Publishing, Hershey, PA, pp. 88-113.

Dawson, C. 2002, Practical research methods : a user-friendly guide to mastering research techniques and projects, How To Books, Oxford.

Duncombe, R., Heeks, R., Kintu, M.J.R. \& Nakangu, B. 2004, eCommerce for small enterprise development a handbook for enterprise support agencies in Uganda, Institute for Development Policy and Management, viewed August 2005, <http://www.ecomm4dev.org/>.

Dutta \& Lopez-Claros, A. 2005, The Global Information Technology Report, 2004-2005 : Efficiency in an increasingly connected world, Palgrave MacMillan, New York.

Economist 2005a, 'Confused in the Andes.' Economist J1 - Economist, vol. 377, no. 8449, p. 40.

Economist 2005b, ‘Free-for-oil.' Economist J1 - Economist, vol. 376, no. 8441, p. 33.

Economist 2006, 'Banana republic.' Economist J1 - Economist, vol. 381, no. 8500, p. 48.

Efendioglu, A.M. \& Yip, V.F. 2004, 'Chinese culture and e-commerce: an exploratory study', Interacting with Computers, vol. 16, no. 1, pp. 45-62.

EIU. 2004, Economist Intelligence Unit E-readiness Rankings 2004, viewed June 2006, $<$ http://graphics.eiu.com/files/ad_pdfs/ERR2004.pdf $>$. 
EIU. 2007, The 2007 e-readiness rankings: Raising the bar, Economist Intelligence Unit - Written in cooperation with The IBM Institute for Business Value.

Faggiani, K.S. 2005, 'Identifying and overcoming barriers to the use of information technology by small business', in M.G. Hunter, S. Burgess \& A. Wenn (eds), Small business and information technology research techniques and international case studies, Heidelberg Press, Heidelberg, Victoria Australia, pp. 3753.

Galperin, H. 2005, 'Wireless networks and rural development: Opportunities for Latin America', Information Technologies and International Development, vol. 2, no. 3, pp. 47-56.

Gammack, J., Asia Pacific Economic Cooperation (Organization). Tourism Working Group., Griffith University School of Management. \& APEC International Centre for Sustainable Tourism. 2004, Development needs of small to medium size tourism businesses : a report prepared for APEC Tourism Working Group, School of Management Griffith Business School Griffith University, [Nathan] Qld.

Gartner, W.C. 2004, 'Factors affecting small firms in tourism: a Ghanaian perspective', in R. Thomas (ed.), Small firms in tourism : international perspectives, Elsevier Ltd, Oxford, pp. 35-52.

Gordon, R.G., Jr 2005, Ethnologue: Languages of the World, Fifteenth edn, SIL International, Dallas, Tex.

Guasch, J.C. \& Ugas, L. 2007, 'The digital gap in Maracaibo city in Venezuela', Telematics and Informatics, vol. 24 , no. 1 , pp. 41-7.

Harris, R.W. 2005, 'Explaining the success of rural Asian telecentres', in R.M. Davison (ed.), Information systems in developing countries : theory and practice, City University of Hong Kong Press, Hong Kong, pp. 83-100.

Harvey, L.J. \& Myers, M.D. 2002, 'Scholarship and practice: the contribution of ethnographic research methods to bridging the gap', in M.D. Myers \& D.E. Avison (eds), Qualitative research in information systems: a reader, Sage Publications, pp. 169-80.

Hawk, S. 2004, 'A comparison of B2C e-commerce in developing countries', Electronic Commerce Research, vol. 4, no. 3, pp. 181-99.

Hine, C. 2000, Virtual ethnography, Sage, London ; Thousand Oaks, Calif.

Inkpen, G. 1994, Information Technology For Travel and Tourism, Pitman, London.

ITU 2005, ICT Statistics 2004, International Telecommunication Union, viewed December 2005, $<$ http://www.itu.int/ITU-D/ict/statistics/>.

Jennex, M.E., Amoroso, D. \& Adelakun, O. 2004, 'E-commerce infrastructure success factors for small companies in developing economies', Electronic Commerce Research, vol. 4, no. 3, pp. 263-86.

Karanasios, S. \& Burgess, S. 2006, 'Exploring the Internet use of small tourism enterprises in developing countries: evidence from a developing country', Electronic Journal of Information Systems in Developing Countries, vol. 27, no. 3, pp. 1-21.

Kirkman, G.S., Cornelius, P.K., Sachs, J.D. \& Schwab, K. 2002, The Global Information Technology Report, 2001-2002 : Readiness for the Networked World, Oxford University Press, New York.

Kuwayama, M. 2001, E-Commerce and export promotion policies for Small and Medium-Sized Enterprises: East Asian and Latin American Experiences, International Trade and Integration Division, United Nations Publications, Santiago, Chile.

Lake, S. 2000, E-Commerce and LDCs: Challenges for enterprises and governments paper presented at the ECommerce and LDCs Roundtable, Kathmandu, Nepal., United Nations Conference on Trade and Development (UNCTAD).

Madon, S. 2005, 'Evaluating e-governance projects in India: a focus on micro-level implementation', in D. Howcroft \& E.M. Trauth (eds), Handbook of critical information systems research : theory and application, E. Elgar Pub., Northampton, Mass., pp. 325-49.

Mann, C.L. 2002, 'Electronic Commerce, Networked Readiness and Trade Competitiveness', in G.S. Kirkman, P.K. Cornelius, J.D. Sachs \& K. Schwab (eds), The Global Information Technology Report: Readiness for the networked world, Oxford University Press, New York, pp. 90-103.

Mead, D.C. \& Liedholm, C. 1998, 'The dynamics of micro and small enterprises in developing countries', World Development, vol. 26, no. 1, pp. 61-74.

Molla, A. \& Licker, P.S. 2005, 'eCommerce adoption in developing countries: a model and instrument', Information \& Management, vol. 42, no. 6, pp. 877-99.

Montealegre, R. 1998, 'Waves of change in adopting the Internet: Lessons from four Latin American countries', Information Technology and People, vol. 11, no. 3, pp. 235-60.

Moodley, S. \& Morris, M. 2004, 'Does e-commerce fulfill its promise for developing country (South African) garment export producers?' Oxford Development Studies, vol. 32, no. 2, pp. 155-78.

Nazmi, N. 2001, 'Failed reforms and economic collapse in Ecuador', The Quarterly Review of Economics and Finance, vol. 41, no. 5, pp. 727-35. 
Neuman, W.L. 1997, Social research methods : qualitative and quantitative approaches, 3rd edn, Allyn and Bacon, Boston.

Oyelaran-Oyeyinka, B. \& Lal, K. 2006, 'Learning new technologies by small and medium enterprises in developing countries', Technovation, vol. 26, no. 2, pp. 220-31.

Payne, J.E. 2002, E-Commerce Readiness for SMEs in Developing Countries: A Guide for Development Professionals, Academy for Educational Development/LearnLink.

Peil, M. 1983, 'Situational Variables', in M. Bulmer \& D.P. Warwick (eds), Social research in developing countries : surveys and censuses in the Third World, UCL Press, London, pp. 71-88.

Poon, A. 1993, Tourism, Technology and Competitive Strategies, CAB International, Wallingford.

Purcell, F., Toland, J. \& Huff, S.L. 2004, 'The potential of e-commerce for remotely located SMEs: Case studies from Samoa', in N.A.Y. Al-Qirim (ed.), Electronic commerce in Small to Medium-Sized Enterprises: Frameworks, Issues and Implications, Idea Group, Hershley, PA, USA, pp. 86-105.

Rizk, N. 2006, 'Venturing the unexplored : e-readiness assessment of small and medium enterprises in Egypt', in S. Kamel (ed.), Electronic business in developing countries : opportunities and challenges, Idea Group Publishing, Hershey, PA, USA, pp. 246-64.

Romero, S. 2000, 'How a byte of knowledge can be dangerous, too', New York Times, vol. 149, no. 51367, p. 4.

Sheldon, J.P. 1997, Tourism Information Technology, CAB International, New York.

Talamanca, C.F., Furlani, A. \& Alves, A. 2006, ICT cluster priority assessment. ICT and SMEs: a strategy framework for the development of the Latin American and Caribbean Region, Multilateral Investment Fund, Inter-American Development Bank, Italian Trust Fund for MIF Project Preparation.

Tanburn, J. \& Singh, A.D. 2001, Innovation and Sustainability in Business Support Services (FIT) - ICTs and Enterprises in Developing Countries: Hype or Opportunity?, International Labour Office, Geneva.

Turner, S. 2003, Indonesia's Small Entrepreneurs : Trading on the Margins, Routledge, London ; New York.

UNCTAD 2004, 'Use of the Internet for efficient international trade: guide for SME managers', paper presented to United Nations Conference on Trade and Development, New York and Geneva.

World Bank. 2000, 'News about World Bank Group Small and Medium Enterprise Initiatives', SME FACTS . vol. 1 , no. 1 , July.

WorldBank 2006, World Development Indicators, The World Bank Group, <http://www.worldbank.org/>.

Wresch, W. 2003, 'Initial e-commerce efforts in nine least developed countries: a review of national infrastructure business approaches and product selection', Journal of Global Information Management, vol. 11 , no. 2 , pp. $667-78$.

WTO 2002, Tourism and Poverty Alleviation, World Tourism Organisation, Madrid. 